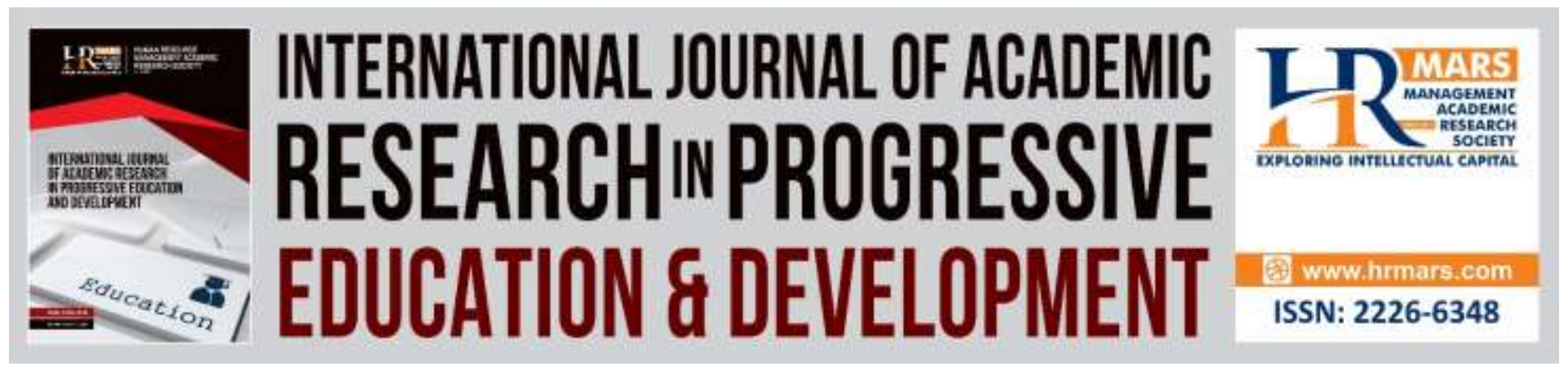

\title{
A Module for the Teaching of Ornamentation, Visual Arts Subject KSSM: An Analysis of Necessity
}

Gopinath Sandra, Harleny Abd Arif, Nor Syazwani Mat Salleh, Azlin Iryani Mohd Noor

To Link this Article: http://dx.doi.org/10.6007/IJARPED/v9-i2/7293

DOI:10.6007/IJARPED/v9-i2/7293

Received: 25 March 2020, Revised: 27 April 2020, Accepted: 23 May 2020

Published Online: 19 June 2020

In-Text Citation: (Sandra et al., 2020)

To Cite this Article: Sandra, G., Arif, H. A., Salleh, N. S. M., \& Noor, A. I. M. (2020). A Module for the Teaching of Ornamentation, Visual Arts Subject KSSM: An Analysis of Necessity. International Journal of Academic Research in Progressive Education and Development, 9(2), 192-204.

Copyright: (C) 2020 The Author(s)

Published by Human Resource Management Academic Research Society (www.hrmars.com)

This article is published under the Creative Commons Attribution (CC BY 4.0) license. Anyone may reproduce, distribute, translate and create derivative works of this article (for both commercial and non-commercial purposes), subject to full attribution to the original publication and authors. The full terms of this license may be seen

at: http://creativecommons.org/licences/by/4.0/legalcode

Vol. 9(2) 2020, Pg. 192 - 204

http://hrmars.com/index.php/pages/detail/IJARPED

JOURNAL HOMEPAGE

Full Terms \& Conditions of access and use can be found at http://hrmars.com/index.php/pages/detail/publication-ethics 


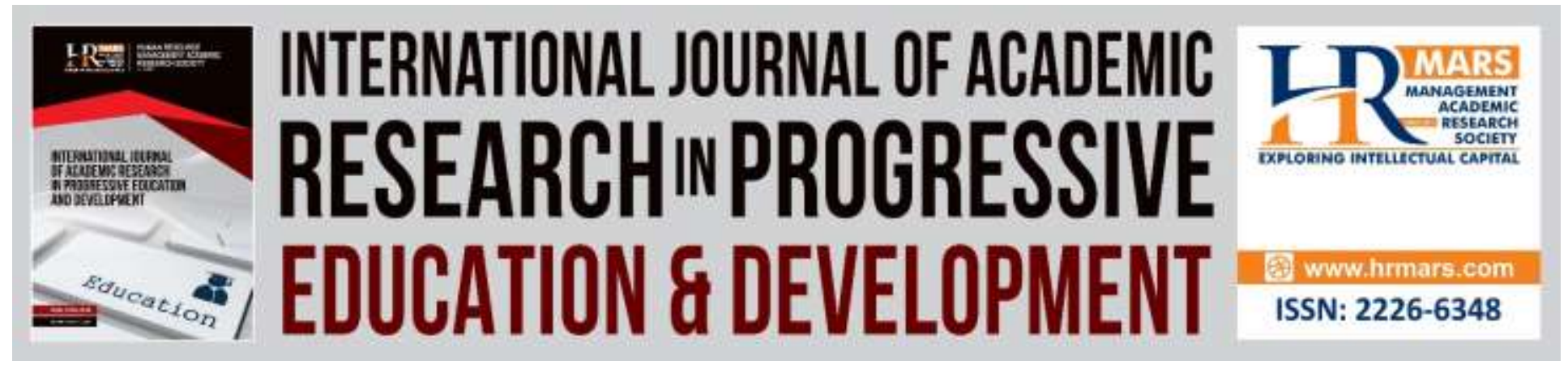

\title{
A Module for the Teaching of Ornamentation, Visual Arts Subject KSSM: An Analysis of Necessity
}

\author{
Gopinath Sandra ${ }^{1}$, Harleny Abd Arif², Nor Syazwani Mat Salleh³, \\ Azlin Iryani Mohd Noor ${ }^{4}$ \\ Department of Art and Design Faculty of Art, Computing and Creative Industry, Sultan Idris \\ Education University, 35900 Tanjong Malim, Perak
}

\begin{abstract}
With the explosion of Industrial Revolution 4.0 the Malaysian Education system faces positive challenges in the Teaching and Learning Process (PdPc) of the country. In line with the Malaysia Education Blueprint (PPPM) 2013-2025 these challenges have set in motion a series of changes in the KSSM. These changes require the Visual Arts subject teachers in secondary schools master the skills of The $21^{\text {st }}$ Century Teaching and Learning Process in classrooms. This research aims to identify the analysis of necessity in the element of constructing a Module for The Teaching of Ornamentation KSSM. This research applies the quantitative method by implementing the Fuzzy Delphi Technique to obtain the research data through the use of questionnaire instruments on Phase 1 level. The total number of respondents involved in this research are 30 Visual Arts subject teachers. The reliability of the instrument of this research is high based on Cronbach's Alpha which is 0.868 . The research findings show that knowledge creates a communicative environment amongst Form 3 Visual Arts subject teachers with the highest Fuzzy Score of 0.713. The development of the Module for the Teaching of Ornamentation KSSM for Visual Arts subject is an effort to aid the Visual Arts subject teachers in secondary schools to control and manage the Teaching and Learning Process (PdPc) in classrooms.

Keywords: KSSM, Module for the Teaching of Ornamentation, $21^{\text {st }}$ Century Teaching and Learning, Fuzzy Delphi Technique

\section{Introduction}

Industrial Revolution 4.0 (IR 4.0), an automation technology involving the use of robots, challenges all areas of our country. IR 4.0 will accelerate the development of a country towards modernization and include the discovery of new technologies such as automation, the Internet of Things (loT), big data analysis, simulation, integrate systems, robotic and cloud applications. Francisco Marmolejo, a World Bank Higher Education Specialist, has argued in the Industrial Revolution 4.0 Seminar, that the nationwide higher education system will respond to the change in IR 4.0 results by having highly skilled, creative and critical thinking individuals. In the meantime,
\end{abstract}


the Malaysia Education Blueprint (PPPM) 2013-2025 began to interact with the elements of the IR 4.0 boom in line with the national education system in the Teaching and Learning Process (PdPc) process in the classroom. The PPPM has reformed the National Education Curriculum in terms of the implementation of the PdPc from the Primary School Integrated Curriculum (KBSR) to the Standard Based Curriculum for Primary Schools (KSSR) 2011 and the Secondary School Integrated Curriculum (KBSM) to the Standard Based Curriculum for Secondary Schools (KSSM) 2017.

Towards this end, with this effort, the Ministry of Education Malaysia (MOE) has introduced Transformation Education focusing on equality of access in international education, giving Malaysians a sense of value, transforming their teaching into a profession of choice, ensuring high-performance leaders are placed in every school and utilizing ICT to improve the quality of learning in Malaysia. All of these changes are implemented through Wave 1, Wave 2 and Wave 3. School Transformation is an effort towards generating superior human capital through a fun learning environment, supported by visionary leadership, competent and highly motivated teachers and strong community commitment. In line with this, PPPM has begun introducing 21st Century Teaching and Learning (PAK21) skills among school teachers so that teachers could achieve the Primary Performance Index focusing on quality and ability.

The PAK21 process in PdPc should include elements such as technology literacy, collaborative learning, and the use of project-based learning approaches as well as applications of high-level thinking, critical thinking to synthesize and evaluate information in solving problems. PAK21 skills include communication, cross-cultural sensitivity, multilingual, management skills, teamwork, creativity, ability to adapt, empathy, stress management, work ethics, self-discipline, responsibility, discriminatory thinking, grammar skills, analytical skills, economics \& business, math skills, computer and telecommunications skills.

To achieve PPPM's aspiration in the national education system, teachers must play an important. Teachers need to have PAK21 knowledge in classroom PdPc. Thus, in the early stages as teach and world progresses, the teacher should change the PdPc method to a more interesting one. There are six characteristics that a teacher needs to master: subject matter, proficient and pedagogical skills, understand students' development and love them, understand learning psychology, have counselling skills and use the latest technology.

The History and Appreciation of Visual Arts is a new field for Level 3 Visual Arts Education subjects according to the Visual Arts Curriculum and Assessment Standard (DSKP) Level 3 Visual Arts Education, this topic of Ornamentation learning is able to generate knowledge by race and ethnicity as well as the contribution of local cultural figures. This KSSM reform, will impact the visual arts education teachers in high school from the PAK21 knowledge aspect when conducting $\mathrm{PdPc}$ in the classroom.

Therefore, this study will review teachers' knowledge of the 21st Century PdPc that Visual Arts Education teachers should have in implementing the PdPc process in line with PPPM requirements

\section{Background Research}

KSSM Visual Arts Education, Form 3 was introduced in 2019 with five major learning areas. Among them are History and Appreciation of Visual Arts, Fine Art, Design, Craft and Visual 
Communication. The History and Appreciation of Visual Arts focuses on the topic of Ornamentation specifically on the various races and ethnic groups in Malaysia such as Malay, Chinese, Indian and ethnic Iban and Kadazan groups. The construction of the Self-taught Learning Module in the field of Art History and Appreciation of KSSM Visual Arts has benefited many parties in the implementation of the 21st Century PdPc process.

\section{Problem Statement}

The 21st Century Education Skills Program is one of the planning and endeavors found in PPPM 2013-2025. The goal of the 21st Century Education Skills is to produce the best possible human capital through the implementation of pedagogy in PdPc in schools. One of the 21st Century Educational Skills that emphasizes inter-racial unity is Cross-Cultural Skills that can help students understand and collaborate in different cultures in our country. This 21st Century Education Skills is implemented in the KSSM Visual Arts Education Form 3 in line with the Student Aspirations contained in the PPPM 2013-2025.

A study conducted by Maaruf (2014), states that studies focusing on cultural responsive pedagogy in Art Education are still lacking both domestically and internationally. In her study, she also noted the limitations of scientific references in the field of culturally responsive pedagogy.

\section{Research Objectives}

Here are the objectives of the study that want to achieve and realize in this study:

(i) Identifying the level of knowledge of Visual Arts Education teachers in the 21st Century PdPc.

\section{Research Questions}

This study will answer the following questions:

(ii) What is the level of knowledge of Visual Arts Education teachers in the 21st Century PdPc? 


\section{Research Framework}

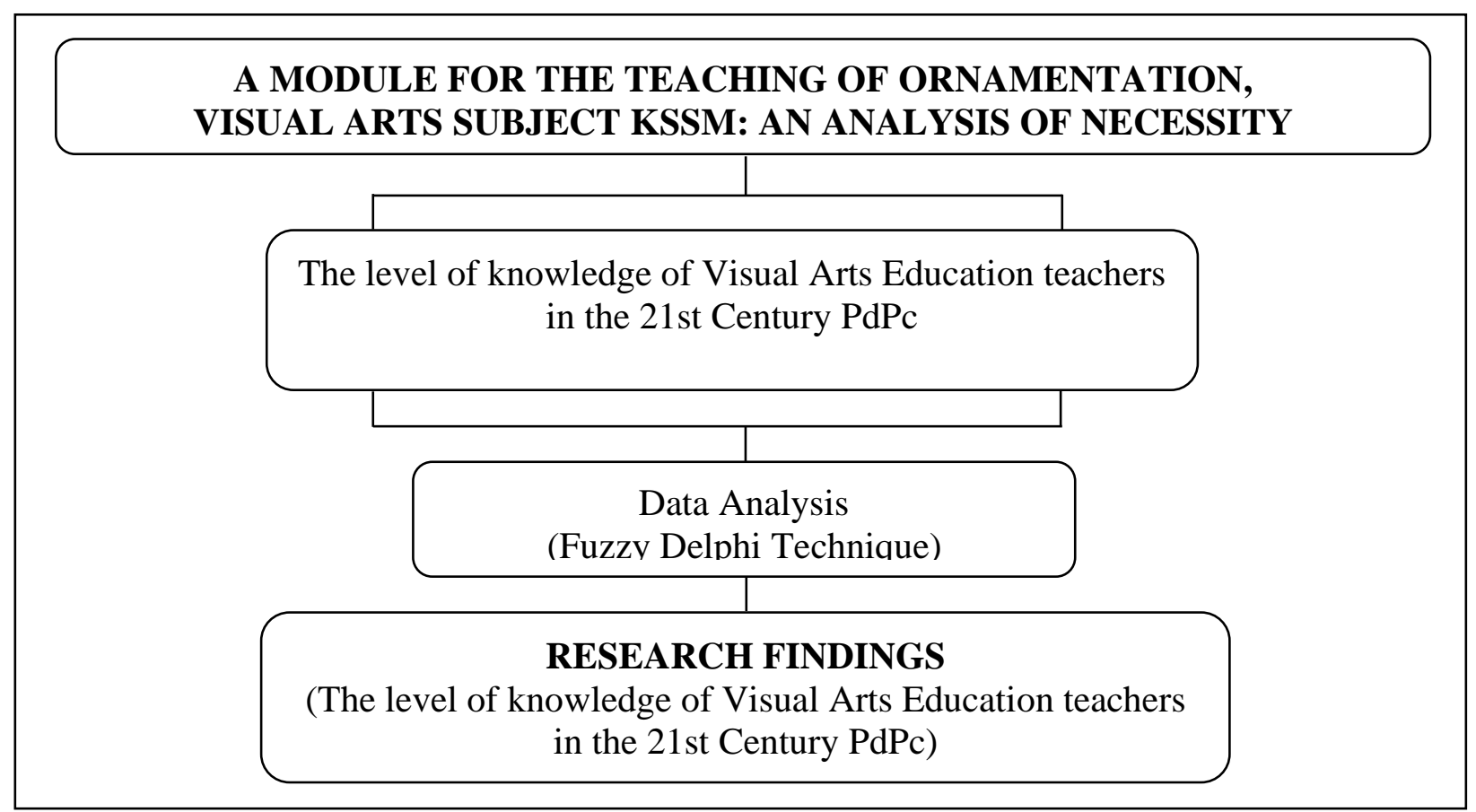

Figure 1. Research Framework

\section{Research Design}

The design of the study selected is a survey with a quantitative approach. Meanwhile, at the analysis stage the needs of the researcher has used the Fuzzy Delphi Technique to analyse the data. The purpose of this stage is to look at the needs of the study. The Fuzzy Delphi technique is a method based on a group of experts used to review and gather opinions to form an agreement on information and a method for obtaining structured data (Muhammad Imran Yousuf, 2007). In this study, the technique was used to obtain expert consensus on the aspect of knowledge level of Visual Arts Education teachers in the 21st Century PdPc.

\section{Research Sample(S)}

According to Berliner (2004), a teacher who has served for five to ten years in a field can be categorized as a specialist. Researchers have selected 30 experts from various states in Malaysia with over five years of service as visual arts education teachers in secondary schools. The number of experts to apply the Fuzzy Delphi Technique are 10 to 50 people are very important in order to achieve high agreement and uniformity in this type of study (Adler and Ziglo, 1996). Table 1.1 shows the number of experts involved in this study. 
Vol. 9, No. 2, 2020, E-ISSN: 2226-6348@ 2020 HRMARS

Table 1. Number of Experts by Teaching Experience, Education Level and Gender

\begin{tabular}{|c|c|c|c|c|c|}
\hline \multirow[b]{2}{*}{ Num. } & \multirow[b]{2}{*}{ Teaching Experiences } & \multicolumn{2}{|c|}{ Level of Education } & \multicolumn{2}{|c|}{ Sex } \\
\hline & & $\begin{array}{l}\text { Bachelor's } \\
\text { Degree } \\
\text { (N) }\end{array}$ & $\begin{array}{l}\text { Master's } \\
\text { (N) }\end{array}$ & $\begin{array}{c}\text { Man } \\
\text { (N) }\end{array}$ & $\begin{array}{c}\text { Women } \\
\text { (N) }\end{array}$ \\
\hline 1. & 0 to 5 years & 0 & 0 & 0 & 0 \\
\hline 2. & 6 to 10 years & 2 & 10 & 1 & 12 \\
\hline 3. & 11 to 15 years & 2 & 9 & 2 & 6 \\
\hline 4. & 16 and more & 4 & 3 & 3 & 6 \\
\hline \multicolumn{2}{|c|}{ Total Number of Experts ( $\mathrm{N}$ ) } & \multicolumn{2}{|c|}{30} & \multicolumn{2}{|c|}{30} \\
\hline
\end{tabular}

\section{Instrument of Study}

The researcher has used questionnaire instruments at the needs analysis stage. At this stage, there are two main sections of the questionnaire, Part A on respondents' demographic information (gender, teaching experience, race, education level and options) and Section $B$ contains 20 items on teacher knowledge of the 21st Century PdPc. The questionnaire was developed courtesy of three experts in the field of Visual Arts Education and a language specialist. The mean reliability coefficient of the instrument with Cronbach's Alpha for this study was 0.868 . It is clear that these questionnaire items have a high level of reliability.

The likert scale used in this questionnaire was 5 points with a score of 1 to 5 which is Very Frequent with a score of 1, Not Very often with a score of 2, Medium Frequent with a score of 3, Frequently with a score of 4 and Very Frequently with a score of 5.

\section{Fuzzy Delphi Technical Data Interprestation}

According to Saido, Siraj, DeWitt \& Al-Amedy (2018), there are three main criteria used to accept or reject an item that has been accepted by the expert. The first and second requirement are bound to each other because they are in the Triangular Fuzzy Numbers section (Hsieh, Lu, \& Tzeng, 2004). The third requirement is in the Defuzzification Process section, which works to see the value of the score according to the priority of an item (Abdelgawad \& Fayek, 2011; Mourhir, Rachidi, \& Karim, 2014). In addition, if the expert group deal value is greater than $75 \%$, then the item is acceptable (Benitez, Martin, \& Román, 2007).

\section{Threshold Value}

The formula in figure 2, is required for the researchers to find the threshold value (d):

$$
\mathbf{d}(\overline{\mathbf{m}}, \overline{\mathbf{n}})=\sqrt{1 / 3\left[\left(\mathbf{m}_{1}-\mathbf{n}_{1}\right)^{2}+\left(\mathbf{m}_{2}-\mathbf{n}_{2}\right)^{2}+\left(\mathbf{m}_{3}-\mathbf{n}_{3}\right)^{2}\right]}
$$

Figure 2. Formula to Find Threshold Value 
INTERNATIONAL JOURNAL OF ACADEMIC RESEARCH IN PROGRESSIVE EDUCATION AND

DEVELOPMENT

Vol. 9, No. 2, 2020, E-ISSN: 2226-6348@ 2020 HRMARS

First Requirement: Data Interpretation

Value $d$, less than or equal to 0.2 , means that all experts reached a consensus on the Item accepted, in reverse if the $d$ value more than 0.2 the item will be unaccepted or second round by experts group.

Table 2. Data interpretation

\begin{tabular}{ccc}
\hline Threshold Value & Description & Interpretation \\
\hline$d \leq 0.2$ & The value of Threshold is less than or equal & Item accepted \\
to 0.2 & Threshold value more than 0.2 & $\begin{array}{c}\text { Item unaccepted or } \\
\text { second round }\end{array}$ \\
\hline
\end{tabular}

\section{Second Requirement: Fuzzy Scale}

Likert-scale data obtained in the first stage were analyzed using the Excel program for better scheduling. All data is converted into a triangular Fuzzy number. Table 3 shows that the higher the number on the scale, the more accurate the data obtained. In this study, the researcher selected the five-point linguistic scale as shown in Table 3.

Table 3. Fuzzy Scale

\begin{tabular}{cc}
\hline Linguistic Variables & Fuzzy Scale \\
\hline Very Frequent & $(0.0,0.0,0.2)$ \\
Not Very often & $(0.0,0.2,0.4)$ \\
Medium Frequent & $(0.2,0.4,0.6)$ \\
Frequently & $(0.4,0.6,0.8)$ \\
Very Frequently & $(0.6,0.8,1.0)$ \\
\hline
\end{tabular}

\section{Third requirement: Defuzzification Process}

The defuzzification process was also carried out in data analysis of the Fuzzy Delphi technique. It is the process of determining the position of each item and variable or sub-variable. In this process, there are three formulas that can be applied and the researcher can choose one of them:

$A \max =1 / 3 *(\mathrm{~m} 1+\mathrm{m} 2+\mathrm{m3})$
$A \max =1 / 4 *(\mathrm{~m} 1+\mathrm{m} 2+\mathrm{m3})$
$A \max =1 / 6 *(\mathrm{~m} 1+\mathrm{m} 2+\mathrm{m3})$

Figure 3. The process to determine ranking based on Fuzzy score

\section{Research Findings}

This study involved 30 experts from various states in Malaysia. All respondents were Visual Arts Education Option teachers with a Bachelor of Arts degree and a Bachelor Degree. The following is a study of the Threshold values of each item for the Visual Arts Education Level of the 21st Century PdPc. 
INTERNATIONAL JOURNAL OF ACADEMIC RESEARCH IN PROGRESSIVE EDUCATION AND

DEVELOPMENT

Vol. 9, No. 2, 2020, E-ISSN: 2226-6348 @ 2020 HRMARS

Table 4. Knowledge Level of Visual Arts Education Teachers in the 21st Century PdPc

\begin{tabular}{|c|c|c|c|c|c|c|c|c|c|c|c|c|c|c|c|c|c|c|c|c|}
\hline \multirow{2}{*}{$\begin{array}{c}\text { Expert } \\
\text { s/ } \\
\text { Items }\end{array}$} & \multicolumn{20}{|c|}{ Knowledge Level of Visual Arts Education Teachers in the 21st Century PdPc } \\
\hline & 1 & 2 & 3 & 4 & 5 & 6 & 7 & 8 & 9 & 10 & 11 & 12 & 13 & 14 & 15 & 16 & 17 & 18 & 19 & 20 \\
\hline \multirow[t]{2}{*}{1} & 0. & 0. & 0. & 0. & 0. & 0. & 0. & 0. & 0. & 0. & 0. & 0. & 0. & 0. & 0. & 0. & 0. & 0. & 0. & 0. \\
\hline & 1 & 2 & 2 & 0 & 1 & 1 & 2 & 2 & 2 & 2 & 1 & 1 & 2 & 3 & 2 & 2 & 2 & 2 & 2 & 1 \\
\hline \multirow[t]{2}{*}{2} & 0. & 0. & 0. & 0. & 0. & 0. & 0. & 0. & 0. & 0. & 0. & 0. & 0. & 0. & 0. & 0. & 0. & 0. & 0. & 0. \\
\hline & 1 & 2 & 2 & 0 & 1 & 1 & 1 & 1 & 2 & 2 & 1 & 2 & 1 & 1 & 2 & 1 & 1 & 2 & 1 & 1 \\
\hline \multirow[t]{2}{*}{3} & 0. & 0. & 0. & 0. & 0. & 0. & 0. & 0. & 0. & 0. & 0. & 0. & 0. & 0. & 0. & 0. & 0. & 0. & 0. & 0. \\
\hline & 2 & 2 & 1 & 0 & 1 & 1 & 1 & 1 & 2 & 2 & 2 & 1 & 1 & 1 & 1 & 1 & 1 & 2 & 1 & 2 \\
\hline \multirow[t]{2}{*}{4} & 0. & 0. & 0. & 0. & 0. & 0. & 0. & 0. & 0. & 0. & 0. & 0. & 0. & 0. & 0. & 0. & 0. & 0. & 0. & 0. \\
\hline & 2 & 4 & 1 & 0 & 1 & 2 & 2 & 1 & 2 & 1 & 1 & 2 & 2 & 3 & 1 & 1 & 1 & 1 & 1 & 1 \\
\hline \multirow[t]{2}{*}{5} & 0. & 0. & 0. & 0. & 0. & 0. & 0. & 0. & 0. & 0. & 0. & 0. & 0. & 0. & 0. & 0. & 0. & 0. & 0. & 0. \\
\hline & 1 & 1 & 1 & 0 & 1 & 1 & 2 & 1 & 2 & 1 & 2 & 1 & 2 & 1 & 2 & 1 & 1 & 2 & 2 & 2 \\
\hline \multirow[t]{2}{*}{6} & 0. & 0. & 0. & 0. & 0. & 0. & 0. & 0. & 0. & 0. & 0. & 0. & 0. & 0. & 0. & 0. & 0. & 0. & 0. & 0. \\
\hline & 1 & 2 & 1 & 0 & 1 & 1 & 1 & 1 & 2 & 2 & 1 & 2 & 2 & 1 & 2 & 2 & 2 & 1 & 1 & 1 \\
\hline \multirow[t]{2}{*}{7} & 0. & 0. & 0. & 0. & 0. & 0. & 0. & 0. & 0. & 0. & 0. & 0. & 0. & 0. & 0. & 0. & 0. & 0. & 0. & 0. \\
\hline & 1 & 1 & 1 & 3 & 1 & 2 & 1 & 1 & 2 & 1 & 1 & 1 & 1 & 1 & 1 & 2 & 1 & 2 & 1 & 1 \\
\hline \multirow[t]{2}{*}{8} & 0. & 0. & 0. & 0. & 0. & 0. & 0. & 0. & 0. & 0. & 0. & 0. & 0. & 0. & 0. & 0. & 0. & 0. & 0. & 0. \\
\hline & 4 & 2 & 1 & 0 & 2 & 1 & 2 & 2 & 2 & 2 & 2 & 1 & 1 & 1 & 2 & 1 & 1 & 1 & 2 & 2 \\
\hline \multirow[t]{2}{*}{9} & 0. & 0. & 0. & 0. & 0. & 0. & 0. & 0. & 0. & 0. & 0. & 0. & 0. & 0. & 0. & 0. & 0. & 0. & 0. & 0. \\
\hline & 1 & 1 & 1 & 0 & 1 & 1 & 1 & 1 & 2 & 1 & 1 & 2 & 1 & 3 & 1 & 1 & 1 & 1 & 1 & 1 \\
\hline \multirow[t]{2}{*}{10} & 0. & 0. & 0. & 0. & 0. & 0. & 0. & 0. & 0. & 0. & 0. & 0. & 0. & 0. & 0. & 0. & 0. & 0. & 0. & 0. \\
\hline & 1 & 2 & 2 & 0 & 2 & 1 & 1 & 2 & 2 & 1 & 2 & 1 & 1 & 1 & 2 & 2 & 2 & 2 & 2 & 2 \\
\hline \multirow[t]{2}{*}{11} & 0. & 0. & 0. & 0. & 0. & 0. & 0. & 0. & 0. & 0. & 0. & 0. & 0. & 0. & 0. & 0. & 0. & 0. & 0. & 0. \\
\hline & 2 & 1 & 1 & 0 & 2 & 1 & 2 & 2 & 2 & 1 & 1 & 2 & 2 & 1 & 2 & 1 & 1 & 1 & 1 & 1 \\
\hline \multirow[t]{2}{*}{12} & 0. & 0. & 0. & 0. & 0. & 0. & 0. & 0. & 0. & 0. & 0. & 0. & 0. & 0. & 0. & 0. & 0. & 0. & 0. & 0. \\
\hline & 1 & 2 & 1 & 0 & 1 & 2 & 2 & 1 & 2 & 1 & 1 & 1 & 1 & 1 & 1 & 1 & 1 & 1 & 1 & 1 \\
\hline \multirow[t]{2}{*}{13} & 0. & 0. & 0. & 0. & 0. & 0. & 0. & 0. & 0. & 0. & 0. & 0. & 0. & 0. & 0. & 0. & 0. & 0. & 0. & 0. \\
\hline & 1 & 2 & 2 & 3 & 1 & 1 & 1 & 1 & 2 & 1 & 1 & 2 & 2 & 1 & 1 & 1 & 1 & 1 & 1 & 1 \\
\hline \multirow[t]{2}{*}{14} & 0. & 0. & 0. & 0. & 0. & 0. & 0. & 0. & 0. & 0. & 0. & 0. & 0. & 0. & 0. & 0. & 0. & 0. & 0. & 0. \\
\hline & 1 & 1 & 2 & 0 & 1 & 1 & 1 & 1 & 2 & 1 & 2 & 1 & 1 & 1 & 1 & 1 & 1 & 2 & 2 & 2 \\
\hline \multirow[t]{2}{*}{15} & 0. & 0. & 0. & 0. & 0. & 0. & 0. & 0. & 0. & 0. & 0. & 0. & 0. & 0. & 0. & 0. & 0. & 0. & 0. & 0. \\
\hline & 1 & 2 & 1 & 0 & 2 & 1 & 2 & 2 & 2 & 1 & 1 & 1 & 1 & 1 & 1 & 2 & 2 & 2 & 2 & 1 \\
\hline 16 & 0. & 0. & 0. & 0. & 0. & 0. & 0. & 0. & 0. & 0. & 0. & 0. & 0. & 0. & 0. & 0. & 0. & 0. & 0. & 0. \\
\hline & 1 & 1 & 1 & 0 & 1 & 2 & 1 & 1 & 2 & 1 & 1 & 2 & 2 & 1 & 1 & 2 & 1 & 2 & 1 & 1 \\
\hline 17 & 0. & 0. & 0. & 0. & 0. & 0. & 0. & 0. & 0. & 0. & 0. & 0. & 0. & 0. & 0. & 0. & 0. & 0. & 0. & 0. \\
\hline & 2 & 4 & 1 & 0 & 1 & 1 & 1 & 2 & 2 & 1 & 1 & 2 & 2 & 1 & 2 & 1 & 1 & 1 & 1 & 1 \\
\hline 18 & 0. & 0. & 0. & 0. & 0. & 0. & 0. & 0. & 0. & 0. & 0. & 0. & 0. & 0. & 0. & 0. & 0. & 0. & 0. & 0. \\
\hline & 2 & 1 & 1 & 0 & 2 & 1 & 1 & 2 & 2 & 1 & 1 & 2 & 2 & 1 & 1 & 1 & 1 & 1 & 1 & 1 \\
\hline 19 & 0. & 0. & 0. & 0. & 0. & 0. & 0. & 0. & 0. & 0. & 0. & 0. & 0. & 0. & 0. & 0. & 0. & 0. & 0. & 0. \\
\hline & 1 & 4 & 1 & 0 & 2 & 1 & 1 & 1 & 2 & 1 & 1 & 2 & 2 & 1 & 1 & 1 & 1 & 1 & 1 & 1 \\
\hline 20 & 0. & 0. & 0. & 0. & 0. & 0. & 0. & 0. & 0. & 0. & 0. & 0. & 0. & 0. & 0. & 0. & 0. & 0. & 0. & 0. \\
\hline & 1 & 1 & 1 & 0 & 2 & 1 & 1 & 2 & 2 & 1 & 1 & 1 & 1 & 1 & 2 & 2 & 1 & 2 & 2 & 2 \\
\hline 21 & 0. & 0. & 0. & 0. & 0. & 0. & 0. & 0. & 0. & 0. & 0. & 0. & 0. & 0. & 0. & 0. & 0. & 0. & 0. & 0. \\
\hline & 1 & 1 & 1 & 0 & 1 & 1 & 1 & 1 & 2 & 2 & 2 & 1 & 1 & 1 & 1 & 2 & & 1 & 1 & 1 \\
\hline
\end{tabular}


Vol. 9, No. 2, 2020, E-ISSN: 2226-6348 @ 2020 HRMARS

$\begin{array}{llllllllllllllllllll}0 . & 0 . & 0 . & 0 . & 0 . & 0 . & 0 . & 0 . & 0 . & 0 . & 0 . & 0 . & 0 . & 0 . & 0 . & 0 . & 0 . & 0 . & 0 . & 0 .\end{array}$ $\begin{array}{llllllllllllllllllll}4 & 2 & 2 & 3 & 2 & 2 & 1 & 1 & 2 & 2 & 2 & 1 & 1 & 3 & 1 & 1 & 1 & 2 & 2 & 2\end{array}$

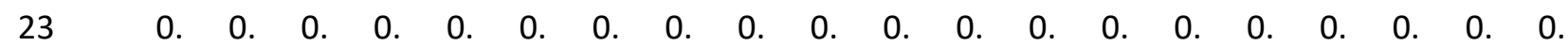

$\begin{array}{llllllllllllllllllll}2 & 1 & 1 & 0 & 1 & 1 & 1 & 1 & 2 & 1 & 2 & 2 & 2 & 1 & 1 & 1 & 1 & 1 & 1 & 1\end{array}$

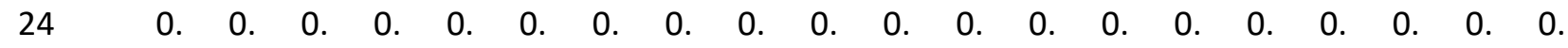

$\begin{array}{lllllllllllllllllllll}1 & 1 & 1 & 0 & 2 & 2 & 1 & 1 & 2 & 1 & 2 & 1 & 2 & 1 & 1 & 2 & 2 & 2 & 1 & 2\end{array}$

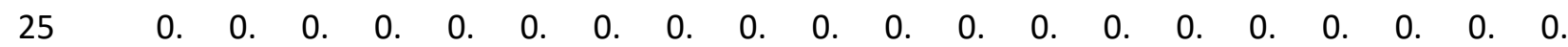

$\begin{array}{llllllllllllllllllll}2 & 4 & 1 & 0 & 2 & 1 & 1 & 1 & 2 & 2 & 2 & 1 & 1 & 3 & 1 & 2 & 2 & 2 & 2 & 2\end{array}$

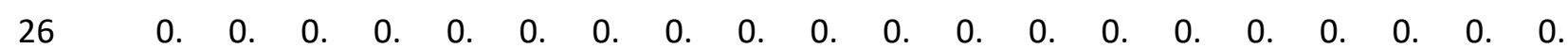

$\begin{array}{llllllllllllllllllll}2 & 1 & 1 & 0 & 1 & 2 & 1 & 2 & 2 & 1 & 1 & 2 & 2 & 1 & 1 & 1 & 1 & 1 & 1 & 1\end{array}$

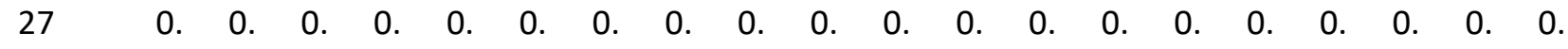

$\begin{array}{llllllllllllllllllll}1 & 1 & 1 & 0 & 1 & 1 & 1 & 2 & 2 & 1 & 1 & 1 & 1 & 1 & 1 & 1 & 1 & 1 & 1 & 2\end{array}$

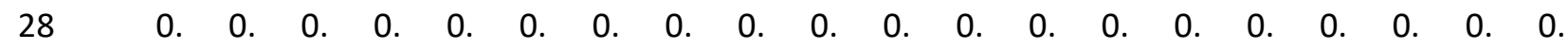

$\begin{array}{llllllllllllllllllll}2 & 1 & 1 & 0 & 2 & 2 & 1 & 2 & 2 & 2 & 2 & 1 & 1 & 1 & 1 & 1 & 1 & 1 & 1 & 2\end{array}$

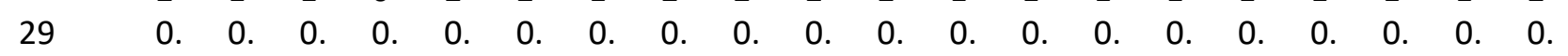

$\begin{array}{lllllllllllllllllllll}30 & 0 . & 0 . & 0 . & 0 . & 0 . & 0 . & 0 . & 0 . & 0 . & 0 . & 0 . & 0 . & 0 . & 0 . & 0 . & 0 . & 0 . & 0 . & 0 . & 0 .\end{array}$

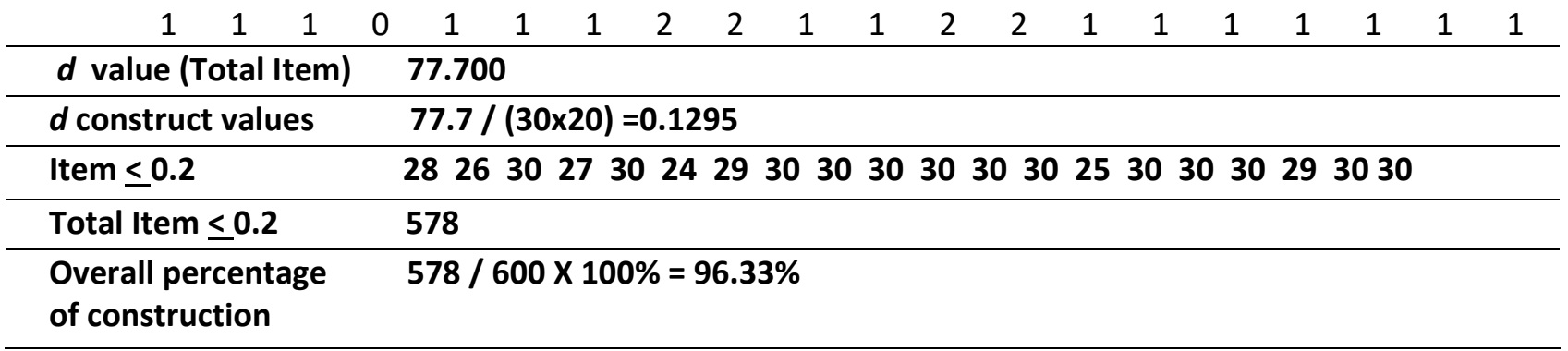

* The $d$ value is the Threshold Value

Based on table 1.4, it is clear that the entire item for the Visual Arts Education Level of Knowledge in the 21st Century PdPc was agreed upon by 30 experts according to the requirements set forth in the Fuzzy Delphi analysis technique. Almost all Threshold constructors ( $d$ constructions) had values of $<0.2$ of 0.1295 . While the overall percentage of construction items according to expert group agreement was $>75 \%$ reaching $96.33 \%$. The following is a table of rankings based on Fuzzy scores based on expert consensus findings. 
INTERNATIONAL JOURNAL OF ACADEMIC RESEARCH IN PROGRESSIVE EDUCATION AND DEVELOPMENT

Vol. 9, No. 2, 2020, E-ISSN: 2226-6348@ 2020 HRMARS

Table 5. Ranking by Fuzzy Scores for Each Visual Arts Education Level Items for 21st Century PdPc

\begin{tabular}{|c|c|c|c|}
\hline $\begin{array}{l}\text { Item } \\
\text { Num. }\end{array}$ & $\begin{array}{c}\text { Knowledge Art Teacher's Knowledge Level Against the } \\
\text { 21st Century PdPc }\end{array}$ & Fuzzy Score & Ranking \\
\hline 12 & Creating a communication environment & 0.713 & 1 \\
\hline 13 & Create a collaborative atmosphere & 0.707 & 2 \\
\hline 9 & Encourages creativity in PdPc & 0.700 & 3 \\
\hline 18 & Be prepared to accept a two-way opinion & 0.693 & 4 \\
\hline 8 & Ensure that the BEST questions are in the assessment & 0.680 & 5 \\
\hline 11 & Encourage critical thinking & 0.680 & 5 \\
\hline 5 & Use appropriate thinking tools & 0.673 & 7 \\
\hline 20 & Controls irrelevant discussions & 0.673 & 7 \\
\hline 10 & Promote innovation in PdPc & 0.667 & 9 \\
\hline 16 & Stimulates the presentation of the work & 0.667 & 9 \\
\hline 15 & $\begin{array}{l}\text { Workshop / classroom layout towards 21st Century } \\
\text { PdPc }\end{array}$ & 0.660 & 11 \\
\hline 19 & Understand student behavior & 0.660 & 11 \\
\hline 6 & Ask questions that can encourage KBAT & 0.653 & 13 \\
\hline 7 & $\begin{array}{l}\text { Create a classroom atmosphere that helps students use } \\
\text { KBAT }\end{array}$ & 0.653 & 13 \\
\hline 2 & State explicit learning objectives in RPH writing & 0.640 & 15 \\
\hline 3 & Plan activities that allow students to use KBAT & 0.640 & 15 \\
\hline 17 & Provides self-assessment at the end of PdPc & 0.640 & 15 \\
\hline 14 & Apply technology literacy & 0.633 & 18 \\
\hline 4 & $\begin{array}{l}\text { Provides Study Aid Material (SAM) that encourages } \\
\text { KBAT }\end{array}$ & 0.620 & 19 \\
\hline 1 & Identify the KBAT elements in the Learning Standard & 0.553 & 20 \\
\hline
\end{tabular}

According to Table 1.5, the Fuzzy scores for the items of the Visual Arts Education Level Against the 21st Century PdPc have influenced the Average of Fuzzy Number values above 0.5. In this case, all 20 items were accepted according to the expert group agreement.

\section{Discussion}

Based on the data obtained from the study, it is found that the level of knowledge of teachers creating a communication environment shows a high overall Fuzzy score of 0.713 . The atmosphere of communication between teachers and pupils is a key agent that should be emphasized in the PdPc process. This is because effective communication between teacher and student facilitates understanding of the delivery of teaching and learning content. In addition, it also provides students with an opportunity to create an awareness of the content of teaching and learning (Khan, Khan, Zia-Ul-Islam, Khan, 2017). In addition, classroom communication can create harmonious relationships between the two parties and enable teachers to identify students who can serve as role models for other students in the PdPc process (Raba, 2017). 
The second highest level of knowledge was to create a collaborative atmosphere with a Fuzzy score of 0.707 . The collaborative learning environment in the classroom encourages students to learn affectively. Collaborations in the PdPc process focus on social and intellectual engagement and create collaboration and teamwork among students (Al-Samarraie \& Saeed, 2018). At the same time, this item also helps students build a sense of responsibility and take on challenges in the community. Furthermore, the collaborative atmosphere of the PdPc process has made students more confident in sharing their ideas (Robinson, Kilgore, \& Warren, 2017).

The third highest item was the creativity boost item in PdPc with a Fuzzy score value of 0.700. A teacher needs to encourage creativity in the PdPc process in terms of activities, the use of Study Aid Material (SAM) and questions that spark ideas (Bereczki \& Karpati, 2018). Teachers can creatively carry out PdPc activities that meet criteria such as communication, collaborative, critical, and creative and value elements (Kettler, Lamb, Willerson \& Mullet, 2018). Among the activities you can do are Think Pair Share, Round Table, Gallery Walk, Hot Seat, Stay Stray and more.

\section{Conclusion}

The nationwide education system leading to the explosion of Industrial Revolution 4.0 has helped to enhance the paradigm of teachers and students in the PdPc process in our country. These challenges began with the reform of the Secondary School Curriculum, providing a positive stimulus for high school Visual Arts Education teachers to master the 21st Century skills. The Selftaught Teaching Module, KSSM Visual Arts Education was developed to help Secondary Visual Arts Education teachers handle the PdPc process in the classroom affectively. The findings of this study have a positive impact on teachers of Level 3 Visual Arts Education subjects. $3 \mathrm{KSSM}$ for Level 3 Visual Arts Education subjects is a new Standard Curriculum in secondary schools. Therefore, the findings of this study can help and serve as a primary source of reference for secondary school teachers in the process of implementing PdPc in the classroom. In addition, the development of the Personal Jewelry Teaching Module also helps school students and students of Institutions of Higher Learning as a source of additional reference in the Teaching and Learning Process. In addition, this study also provides scientific information that can be referenced by social institutions or organizations such as Hinduism as well as a reading material for the public to better understand the identity of various ethnics and jewellery in our country.

\section{Corresponding Author}

Gopinath Sandra

Department of Art and Design

Faculty of Art, Computing and Creative Industry, Sultan Idris Education University, 35900 Tanjong Malim, Perak, Malaysia

Email: gopinathsandra@yahoo.com.my 
INTERNATIONAL JOURNAL OF ACADEMIC RESEARCH IN PROGRESSIVE EDUCATION AND

DEVELOPMENT

Vol. 9, No. 2, 2020, E-ISSN: 2226-6348 @ 2020 HRMARS

\section{References}

Abdelgawad, M., \& Fayek, A. R. (2011). Fuzzy Reliability Analyzer: Quantitative Assessment of Risk Events in The Construction Industry Using Fuzzy Fault-Tree Analysis. Journal of Construction Engineering and Management, 137(4), 294-302.

Abdelgawad, M., \& Fayek, A. R. (2011). Fuzzy Reliability Analyzer: Quantitative Assessment of Risk Events in The Construction Industry Using Fuzzy Fault-Tree Analysis. Journal of Construction Engineering and Management, 137(4), 294-302.

Alamgir, K., Salahuddin, K., Syed, Z. U. I., Khan., \& Manzoor. (2017). Communication Skills of a Teacher and Its Role in the Development of the Students' Academic Success. Journal of Education and Practice, 8(1), 18-21.

Al-Samarraie, H., \& Saeed, N. (2018). A systematic review of cloud computing tools for collaborative learning: Opportunities and challenges to the blended-learning environment. Computers and Education, 124, 77-91.

Arif, H. A., Idris, M. Z., Zali, A. Z. Z., \& Zaid, S. R. N. M. (2018). Pendidikan Seni Visual Tingkatan 3. Kuala Lumpur: Telaga Biru Sdn. Bhd.

Bahagian Pembangunan Kurikulum. (2012). Pelan Pembangunan Pendidikan Malaysia (PPPM), 2013-2025. Kuala Lumpur: Kementerian Pendidikan Malaysia.

Bahagian Pembangunan Kurikulum. (2015). Kurikulum Standard Sekolah Menengah, Pendidikan Seni Visual. Kuala Lumpur: Kementerian Pendidikan Malaysia.

Bahagian Pembangunan Kurikulum. (2017). Kurikulum Standard Sekolah Menengah, Pendidikan Seni Visual Tingkatan 3. Kuala Lumpur: Kementerian Pendidikan Malaysia.

Benitez, J. M., Martín, J. C., \& Román, C. (2007). Using Fuzzy Number for Measuring Quality of Service in The Hotel Industry. Tourism Management, 28(2), 544-555.

Bereczki, E. O., \& Karpati, A. (2018). Teachers' Beliefs About Creativity and Its Nurture: A Systematic Review of The Recent Research Literature. Educational Research Review 23 (2), 25-56.

Buku Penerangan Kurikulum Standard Sekolah Menengah. (KSSM) (2016). Kuala Lumpur:Bahagian Pembangunan Kurikulum, Kementerian Pendidikan Malaysia.

Chua, Y. P. (2012). Kaedah dan StatistikPenyelidikan Buku 2: Asas Statistik Penyelidikan. Mc Graw Hill Education.

Dewan Bahasa dan Pustaka. (2005). Kamus Dewan Edisi Keempat. Kuala Lumpur: Dawama Sdn.Bhd.

Hamid, M. J. A. (2006). Asas Seni Visual. Perak: Penerbit Universiti Pendidikan Sultan Idris.

Hsieh, T. Y., Lu, S. T \& Tzeng, G. H. (2004). Fuzzy MCDM Approach for Planning and DesignTenders Selection in Public Office Buildings. International Journal of Project Management, 22 (7), 573-584.

Ibrahim, M. N., \& Hassan, I. (2003). Pendidikan Seni Untuk Maktab \& Universiti. Pahang: PTS Publication \& Distributors Sdn. Bhd.

Idris, N. (2010). Penyelidikan dalam Pendidikan. Kuala Lumpur: Mc Graw-Hill (Malaysia) Sdn. Bhd.

Kettler, T., Lamb, K. N., Willerson, A., \& Mullet, D. R. (2018). Teachers' Perceptions of Creativity in the Classroom. Creativity Research Journal, 30(2), 164-171.

Lebar, O. (2017). Penyelidikan Kualitatif Pengenalan kepada Teori dan Metode. Perak: Penerbit Universiti Pendidikan Sultan Idris. 
INTERNATIONAL JOURNAL OF ACADEMIC RESEARCH IN PROGRESSIVE EDUCATION AND

DEVELOPMENT

Vol. 9, No. 2, 2020, E-ISSN: 2226-6348 @ 2020 HRMARS

Maaruf, S. Z. (2014). E-Modul Pedagogi Responsif Budaya Pedagogi Kraf Tradisional Pendidikan Seni Visual. Shah Alam: Universiti Teknologi Mara.

Mourhir, A., Rachidi, T., \& Karim, M. (2014). River Water Quality Index for Morocco Using A Fuzzy Inference System. Environmental Systems Research, 3(1), 84-12.

Noah, S. M. N., \& Ahmad, J. (2017). Pembinaan Modul Latihan dan Modul Akademik. Selangor: Percetakan Mesbah Sdn. Bhd.

Pusat Perkembangan Kurikulum. (2001). Falsafah Pendidikan Kebangsaan, Matlamat dan Misi Kementerian Pendidikan Malaysia. Kuala Lumpur: Kementerian Pendidikan Malaysia.

Raba, A. A. A. (2017). The Influence of Think-Pair-Share (TPS) on Improving Students' Oral Communication Skills in EFL Classrooms. Creative Education, 8, 12-23.

Riji, H. M., \& Ahmad, S. (2014). Kaedah Penyelidikan Kualitatif. Selangor: Universiti Putra Malaysia Press.

Robinson, H. A., Kilgore, W., \& Warren, S. J. (2017). Care, Communication, Learner Support: Designing Meaningful Online Collaborative Learning. Online Learning, 21(4), 29-51.

Rohidi, T. R. (2011). Metodologi Penelitian Seni. Indonesia: Penerbit Cipta Prima Nusantara Semarang, CV.

Saido, G. A. M., Siraj, S., DeWitt, D., \& Al-Amedy, O. S. (2018). Development of An Instructional Model for Higher Order Thinking in Science Among Secondary School Students: A Fuzzy Delphi Approach: International Journal of Science Education, 40(8), 847-866. 